\title{
Gastrointestinal Bleeding with Hemodynamic Repercussion due to a Gastric Metastatic Lesion of a Testicular Choriocarcinoma in a Previously Asymptomatic Young Adult
}

\author{
Omar Al Salman ${ }^{\mathrm{a}}$ Fahad Malik $^{\mathrm{b}}$ Shashank Trivedi ${ }^{\mathrm{a}}$ Marwah Alchalabi ${ }^{\mathrm{a}}$ \\ Shobhana Chaudharia \\ ${ }^{\mathrm{a}}$ Internal Medicine, Metropolitan Hospital Center, New York, NY, USA; ${ }^{\mathrm{b}}$ Internal Medicine, Richmond University \\ Medical Center, Staten Island, NY, USA
}

Keywords

Anemia · Choriocarcinoma · Endoscopy · Gastric cancer . Upper gastrointestinal bleeding

\section{Hemorragia gastrointestinal com repercussão hemodinâmica devido a metástase gástrica de um coriocarcinoma testicular num doente previamente assintomático}

\section{Palavras Chave}

Anemia - Coriocarcinoma - Endoscopia · Cancro gástrico · Hemorragia digestiva alta

A 25-year-old male with a past medical history of psoriasis on maintenance treatment with adalimumab presented to the emergency department with intermittent episodes of painless rectal bleeding associated with shortness of breath on exertion for the last 2 weeks. On physical examination, he was a young male with pallor, tachycardia, and frank blood on rectal examination. Laboratory data was significant for a hemoglobin level of $5.8 \mathrm{~g} / \mathrm{dL}$. He

\section{KARGER}

karger@karger.com www.karger.com/pjg
(C) 2019 Sociedade Portuguesa de Gastrenterologia Published by S. Karger AG, Basel

Karger

Upen access

This article is licensed under the Creative Commons AttributionNonCommercial-NoDerivatives 4.0 International License (CC BYNC-ND) (http://www.karger.com/Services/OpenAccessLicense) Usage and distribution for commercial purposes as well as any distribution of modified material requires written permission. required intravenous fluids and blood transfusions for resuscitation. An upper endoscopy detected an ulcerated, friable mass with a size of $2 \times 2 \mathrm{~cm}$ in the gastric fundus with no active bleeding (Fig. 1). Histopathology of the gastric mucosa showed metastatic choriocarcinoma (Fig. 2, 3). A whole-body computed tomography demonstrated multiple metastatic pulmonary and gastrointestinal lesions along with an irregular mass of the right testicle. Scrotal ultrasound confirmed this mass and was considered to be the possible primary source of malignancy. He underwent right inguinal orchiectomy, and histopathology was also consistent with choriocarcinoma.

The patient's human chorionic gonadotropin (HCG) level was $90,911 \mathrm{mIU} / \mathrm{mL}$ (normal, $\leq 1 \mathrm{mIU} / \mathrm{mL}$ ). He began with chemotherapy. However, he continued to have intermittent episodes of melena and drop in his hemoglobin. A second upper endoscopy showed active oozing of blood with concerns for increase in size of the gastric mass (Fig. 4). He underwent embolization of the left gastric artery to achieve hemostasis by interventional radiology. He was safely discharged home a few days later and now follows up in the outpatient oncology clinic for chemotherapy. 


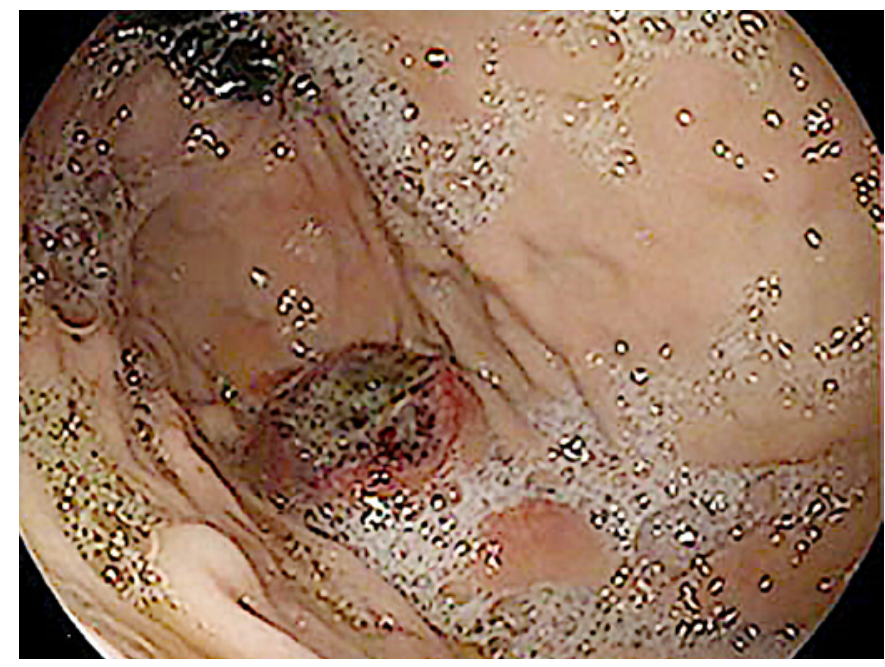

Fig. 1. An ulcerated, necrotic, and friable mass with a size of approximately $2 \times 2 \mathrm{~cm}$ in the gastric fundus is shown.

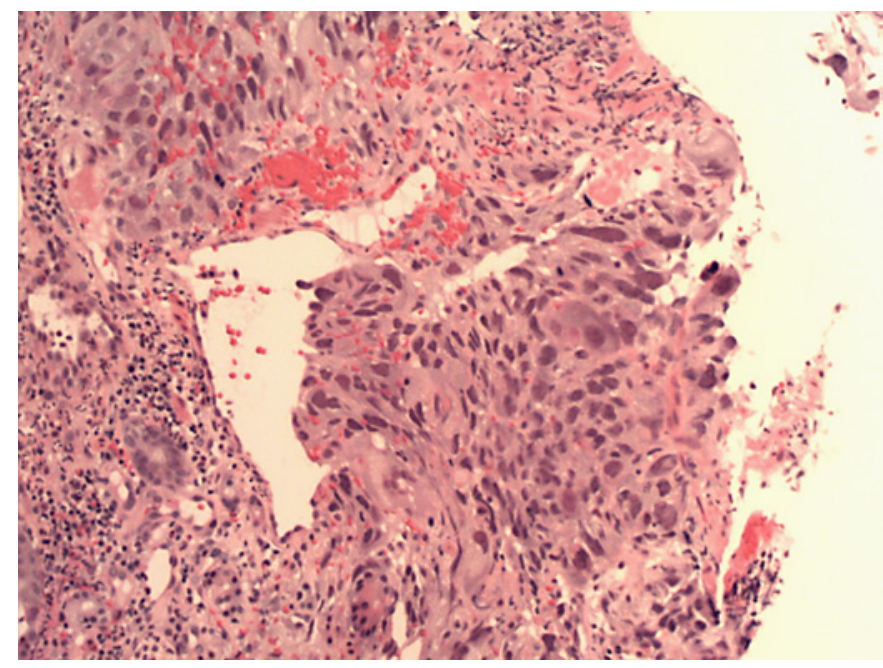

Fig. 2. A metastatic choriocarcinoma in the gastric fundus ( $H \& E$ staining) is shown.

Testicular germ cell (TGC) tumors are extremely rare tumors accounting for less than $2 \%$ of malignancies in the male population [1]. A pure testicular choriocarcinoma (TC) represents $0.3 \%$ of these TGC tumors and is known to be a very aggressive form [2]. Most of these cases present with hematogenous spread to multiple organs by the time of diagnosis, with survival rates lower than 30\% [3]. Gastrointestinal involvement occurs in less than 5\% from primary TC and can present as hematemesis or melena. Bleeding can also occur in any other organs such as lungs, brain, or peritoneum [1].

Testicular Choriocarcinoma with Gastric Metastasis

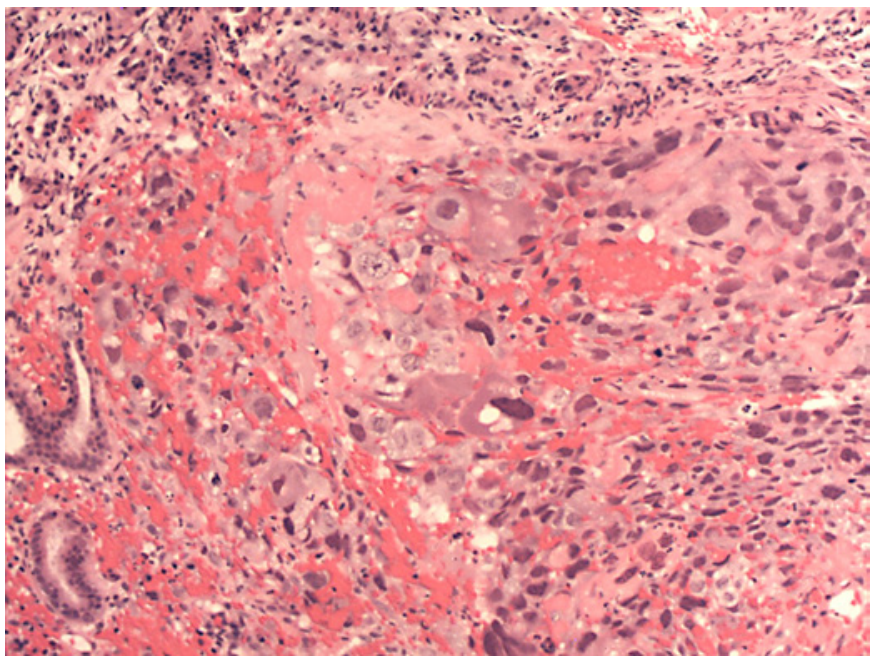

Fig. 3. A metastatic choriocarcinoma in the stomach showing cytotrophoblasts and syncytiotrophoblasts.

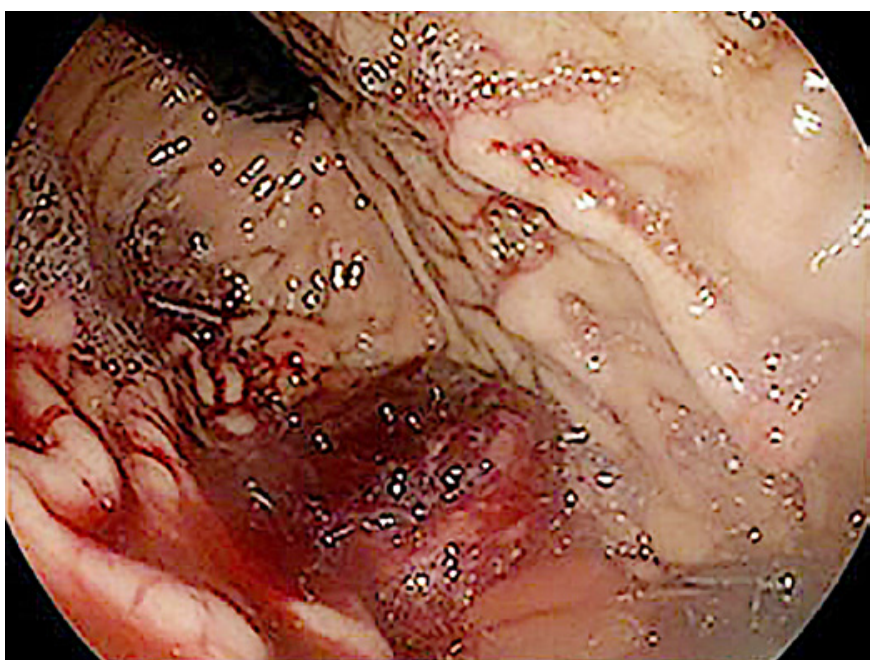

Fig. 4. An ulcerated, necrotic, and friable mass with a size of approximately $2 \times 2 \mathrm{~cm}$ in the gastric fundus with active bleeding is shown.

Serum HCG testing proves as a useful noninvasive marker even in men for detection and monitoring of this malignancy $[1,4]$. Young men with gastric ulceration should always have a thorough genital physical examination and should be investigated further to exclude any concerns of malignancy. These patients might not have any urologic symptoms like in our patient, and melena could be the first manifestation of a testicular malignancy. 


\section{Statement of Ethics}

The authors state that the subject has given written informed consent.

\section{Disclosure Statement}

The authors have no conflicts of interest to declare.

\section{Author Contributions}

O.A., F.M., S.T., M.A., and S.C. all contributed to writing, editing, and supervision of the manuscript.
1 Lowe K, Paterson J, Armstrong S, Walsh S, Groome M, Mowat C: Metastatic testicular choriocarcinoma: a rare cause of upper GI bleeding. ACG Case Rep J. 2015 Oct;3(1):36-8.

2 Lee SC, Kim KH, Kim SH, Lee NS, Park HS, Won JH: Mixed testicular germ cell tumor presenting as metastatic pure choriocarcinoma involving multiple lung metastases that was effectively treated with high-dose chemotherapy. Cancer Res Treat. 2009 Dec;41(4): 229-32.

3 Yokoi K, Tanaka N, Furukawa K, Ishikawa N, Seya T, Horiba K, et al: Male choriocarcinoma with metastasis to the jejunum: a case report and review of the literature. J Nippon Med Sch. 2008 Apr;75(2):116-21.

4 Sesterhenn IA, Davis CJ Jr: Pathology of germ cell tumors of the testis. Cancer Contr. 2004 Nov-Dec;11(6):374-87. 